\title{
Identification and Characterization of Citrus Chlorotic Spot Virus, a New Dichorhavirus Associated with Citrus Leprosis-Like Symptoms
}

C. Chabi-Jesus, Instituto Biológico, São Paulo, SP, Brazil; and PPG Microbiologia Agrícola ESALQ/USP, Piracicaba, SP, Brazil; P. L. Ramos-González, Instituto Biológico, São Paulo; A. D. Tassi, LFN/ESALQ/USP, 13418-900 Piracicaba, SP, Brazil; O. Guerra-Peraza, Instituto Biológico, São Paulo; and Citrus Research \& Education Center, University of Florida; E. W. Kitajima, LFN/ESALQ/USP; R. Harakava, Instituto Biológico, São Paulo; J. E. A. Beserra, Jr., Universidade Federal do Piauí, Teresina, PI, Brazil; R. B. Salaroli, LFN/ESALQ/USP; and J. Freitas-Astúa, ${ }^{\dagger}$ Instituto Biológico, São Paulo; and Embrapa Mandioca e Fruticultura, Cruz das Almas, BA, Brazil

\begin{abstract}
Local chlorotic spots resembling early lesions characteristic of citrus leprosis (CL) were observed in leaves of two sweet orange (Citrus sinensis L.) trees in Teresina, State of Piauí, Brazil, in early 2017. However, despite the similarities, these spots were generally larger than those of a typical CL and showed rare or no necrosis symptoms. In symptomatic tissues, transmission electron microscopy revealed the presence of viroplasms in the nuclei of the infected parenchymal cells and rod-shaped particles with an average size of approximately $40 \times 100 \mathrm{~nm}$, resembling those typically observed during infection by dichorhaviruses. A bipartite genome of the putative novel virus, tentatively named citrus chlorotic spot virus (CiCSV) $($ RNA1 $=6,518$ nucleotides [nt] and RNA2 $=5,987 \mathrm{nt}$ ), revealed the highest nucleotide sequence identity values with the dichorhaviruses coffee ringspot virus

strain Lavras (73.8\%), citrus leprosis virus N strain Ibi1 (58.6\%), and orchid fleck virus strain So (56.9\%). In addition to citrus, CiCSV was also found in local chlorotic lesions on leaves of the ornamental plant beach hibiscus (Talipariti tiliaceum (L.) Fryxell). Morphological characterization of mites recovered from the infected plants revealed at least two different types of Brevipalpus. One of them corresponds to Brevipalpus yothersi. The other is slightly different from $B$. yothersi mites but comprises traits that possibly place it as another species. A mix of the two mite types collected on beach hibiscus successfully transmitted CiCSV to arabidopsis plants but additional work is required to verify whether both types of flat mite may act as viral vectors. The current study reveals a newly described dichorhavirus associated with a citrus disease in the northeastern region of Brazil.
\end{abstract}

Citrus leprosis (CL) is a viral disease endemic in the Americas that reduces yields and threatens the sustainability of citrus orchards (Bastianel et al. 2010; Roy et al. 2015a). CL does not systemically spread within the infected plants, only producing chlorotic lesions that are regularly accompanied by a central region, and sometimes concentric rings, displaying necrotic tissues. Commonly, the disease induces premature leaf and fruit drop. Severe infections of twigs and stems may also lead to the death of branches and, occasionally, the whole tree.

$\mathrm{CL}$ is caused by members of a heterogeneous group of rod-shaped or bacilliform single-stranded (ss)RNA viruses assigned to the genera Cilevirus, Higrevirus, and Dichorhavirus (Dietzgen et al. 2014; LocaliFabris et al. 2012; Melzer et al. 2012). In the infected cells, viruses of the two first genera replicate in the cytoplasm, whereas dichorhaviruses replicate and accumulate in the nucleus, which is a trait that identifies two kinds of CL: cytoplasmic type (CL-C) and nuclear type (CL-N) (Rodrigues et al. 2003). CL-C is widely distributed throughout the main commercial citrus areas in Latin America. Citrus leprosis virus $\mathrm{C}$ (CiLV-C, genus Cilevirus) is prevalent in sweet orange orchards in the region, and its population is genetically subdivided into two clades which have a different and contrasted geographic distribution (Locali-Fabris et al. 2006; Ramos-González et al. 2016a). CiLV-C strains from the clade SJP (São Jose do Rio Preto) have been only detected thus far in commercial areas in the State of São Paulo, Brazil,

${ }^{\dagger}$ Corresponding author: J. Freitas-Astúa; E-mail: juliana.astua@embrapa.br

C. Chabi-Jesus and P. L. Ramos-González contributed equally to this work.

Funding: This work was partially supported by Conselho Nacional de Desenvolvimento Científico e Tecnológico (375843/2012-4 and 401564/2012-6) and Fundação de Amparo à Pesquisa do Estado de São Paulo (2014/08458-9 and 2016/01960-6).

*The $\boldsymbol{e}$-Xtra logo stands for "electronic extra" and indicates that one supplementary figure and two supplementary tables are published online.

Accepted for publication 24 February 2018.

() 2018 The American Phytopathological Society whereas those from the clade CRD (Cordeirópolis) circulate all over the continent. In addition to CiLV-C, in Colombia, CL-C is also caused by the cilevirus citrus leprosis virus $\mathrm{C} 2$ (CiLV-C2), whose genome shares only 55\% nucleotide identity with CiLV-C (Roy et al. 2013a). Hibiscus green spot virus 2 is the only higrevirus identified to date and infects mainly hibiscus plants. However, it has been reported to be associated with CL-like symptoms in a few Volkamerian lemon (Citrus volkameriana Tan. \& Pasq.) and navel sweet orange (C. sinensis) plants in Hawaii without causing any damage to the local citrus industry (Melzer et al. 2012; Roy et al. 2015a). Meanwhile, CL-N is much less frequent but it may affect a broader array of citrus commercial species; for example, sweet orange, lemon (Citrus $\times$ limon) (L.) Burm. F., sour orange (C. aurantium L.), grapefruit $(C . \times$ paradise) Macfadyen, lime (C. aurantiifolia) (Christm.) Swingle, mandarin (C. reticulata) Blanco, Persian lime $(C . \times$ latifolia $)$ Tanaka, and so on (Cruz-Jaramillo et al. 2014; Roy et al. 2015b). Currently, two dichorhaviruses cause CL-N. Citrus-infecting strains of orchid fleck virus (OFV-citrus) have been found affecting small orchards in Mexico and Colombia (Cruz-Jaramillo et al. 2014; Roy et al. 2014, 2015b). Isolated foci of infection by citrus leprosis virus N (CiLV-N) have been detected in noncommercial areas of the State of São Paulo, Brazil (Ramos-González et al. 2017). An archaic isolate of a CL-Ncausing dichorhavirus was identified in a herbarium sample collected in Florida in 1948 but it seems that this virus may not exist in nature any longer (Hartung et al. 2015).

Genus Brevipalpus (Arachnida: Acari: Tenuipalpidae) comprises more than 280 valid species of known flat or false spider mites from which, thus far, 5 have been implicated in the transmission of CL-causing viruses (Beard et al. 2015; Childers et al. 2003; Kitajima and Alberti 2014; Mesa et al. 2009). Citrus-infecting strains of OFV are transmitted by Brevipalpus californicus (Banks) (GarcíaEscamilla et al. 2017), and transmission of CiLV-N has been confirmed using viruliferous mites of the species $B$. phoenicis sensu stricto (Geijskes) (Ramos-González et al. 2017). Much earlier, B. obovatus mites were considered the vector of CL pathogens, probably those associated with the CL-C type of the disease, in Argentina (Frezzi 1940; Knorr 1968; Vergani 1945). Transmission of viruses causing CL-C also involves the mite species $B$. yothersi and B. papayensis (Nunes et al. 2018; Ramos-González et al. 2016a). 
In Brazil and Mexico, B. yothersi mites are frequently found in citrus orchards and in CiLV-C-infected trees (Roy et al. 2015a; Sánchez-Velázquez et al. 2015). In Colombia, in addition to the transmission of CiLV-C, B. yothersi seems to be the vector of CiLV-C2 (León et al. 2017). Apparent differences during transmission to sweet orange plants of members of the clades SJP and CRD of CiLV-C by B. yothersi mites have not been observed (Arena et al. 2016). Both cileviruses and dichorhaviruses are persistently transmitted by their corresponding vectors but, although dichorhaviruses appear to replicate in the mite cells (Kitajima and Alberti 2014; Roy et al. 2015a), there is still some controversy regarding the cileviruses. Negative-strand specific cDNA corresponding to cileviruses have been detected in Brevipalpus mites (Roy et al. 2015a) but extensive biological and anatomical evidence suggests no multiplication of these viruses in their vectors (Alberti and Kitajima 2014; Tassi et al. 2017).

Virions of the genus Dichorhavirus (family Rhabdoviridae) encapsidate two (-)ssRNA molecules that globally encode six open reading frames (ORF) (Dietzgen et al. 2017). ORF 1 to 5 span over the RNA1, are nonoverlapped, and encode monocistronic messenger RNA for the translation of the nucleocapsid $(\mathrm{N})$, phosphoprotein $(\mathrm{P})$, putative movement protein (MP), matrix protein $(\mathrm{M})$, and glycoprotein $(\mathrm{G})$, respectively. RNA2 harbors only one ORF that encodes the RNAdependent RNA polymerase (RdRP or L). Sequences comprising regulatory elements involved in the transcription initiation and the polyadenylation signaling processes flank all of these ORF. Nucleotide sequence stretches between contiguous ORF may show different lengths and composition, a trait linked to the evolutionary history of invertebrate- and vertebrate-infecting rhabdoviruses (Walker et al. 2015).

In this current work, we describe the ensemble of morphological and molecular evidence that allowed us to identify a new dichorhavirus associated with CL-like symptoms in sweet orange trees in Teresina, State of Piauí (PI), in northeastern Brazil. In addition to citrus, a similar virus was also found in beach hibiscus plants (Talipariti tiliaceum (L.) Fryxell), an ornamental tree used in public gardens of that city. We also describe the Brevipalpus mite transmission of CiCSV from infected beach hibiscus to arabidopsis plants using two different types of mites found in beach hibiscus. In that natural host, in addition to $B$. yothersi mites, another type of mite, morphologically closer to $B$. yothersi, was found. The new type is slightly distinct and might represent a novel Brevipalpus sp. associated with viral transmission. Mites belonging to the new Brevipalpus type were only detected in the sweet orange trees infected by CiCSV thus far.

\section{Materials and Methods}

Biological samples. Branches from two sweet orange (C. sinensis L., family Rutaceae) trees (i.e., samples 1 and 2) displaying large chlorotic spots were collected in urban areas of the city of Teresina, PI, Brazil, in February 2017. In addition, leaves of the ornamental beach hibiscus (T. tiliaceum (L.) Fryxell; syn. Hibiscus tiliaceus L., family Malvaceae) were collected $4 \mathrm{~km}$ away from the sampled citrus trees in November 2017. Beach hibiscus leaves showed localized chlorotic lesions, although smaller than those found in citrus. Rare necrotic lesions were observed. Each sample was subdivided and separately sent to two laboratories in the State of São Paulo, Brazil. Pieces from both symptomatic and asymptomatic leaf tissues were cut and conserved at $-80^{\circ} \mathrm{C}$ until RNA extraction at the Instituto Biológico (Plant Biochemistry and Phytopathology Laboratory), in São Paulo. Transmission electron microscopy (TEM) analysis of plant tissues and the identification of mites found on samples were carried out at the Escola Superior de Agricultura Luiz de Queiroz, University of São Paulo, in Piracicaba. All mites from citrus samples were fixed in a $90 \%$ ethanol solution until their morphoanatomical inspection. Of the total number of mites found in the beach hibiscus sample, a fraction was used for virus transmission experiments and the rest were fixed to proceed with their taxonomical identification.

TEM. Small fragments of leaf lesions from both citrus and beach hibiscus were prefixed for at least $2 \mathrm{~h}$ in a modified Karnovsky solution (2.5\% glutaraldehyde and $2 \%$ paraformaldehyde in $0.05 \mathrm{M}$ cacodylate buffer, $\mathrm{pH}$ 7.2) (Kitajima and Nome 1999). Tissue samples were postfixed in $1 \% \mathrm{OsO}_{4}$, dehydrated, embedded in low viscosity
Spurr epoxy resin, and sectioned with a Leica EM UC6 ultramicrotome (Vienne, Austria) equipped with a Diatome diamond knife (Biel, Switzerland). Sections were mounted on 300-mesh copper grids and stained with uranyl acetate and Reynold's lead citrate and examined in a JEM 1011 (JEOL, Akishima, Japan) transmission electron microscope, and the images recorded digitally.

Detection of known CL viruses by reverse-transcription polymerase chain reaction. Total RNA was extracted from approximately $100 \mathrm{mg}$ of plant samples using Trizol and following the manufacturer's recommendations (Life Technologies, Foster City, CA). Approximately 500 ng of the RNA template was used to obtain the cDNA using random hexamer primers and the GoScript reverse-transcription (RT) kit, as described by the manufacturer (Promega Corp., Madison, WI). The cDNA solution $(3 \mu \mathrm{l})$ was tested by polymerase chain reaction (PCR) using an array of specific primers for the detection of all known citrus cileviruses and dichorhaviruses (Supplementary Table S1). Amplicons were separated on $1.0 \%$ agarose gels in $1 \times$ Trisacetate-EDTA and visualized with ethidium bromide $(0.1 \mu \mathrm{g} / \mathrm{ml})$. RNA extracts from plants infected with the following viruses were used as control: coffee ringspot virus CoRSV (isolate collected in Limeira, SP, Brazil), CiLV-N (isolate collected in Ibiúna, SP, Brazil), OFVcitrus (isolate collected in Guadalajara, Mexico, kindly provided by Dr. Otero-Colina, Colegio de Postgraduados, Texcoco, Mexico), OFV-orchid (isolate collected in Piracicaba, SP, Brazil), clerodendrum chlorotic spot virus (ClCSV, putative dichorhavirus not yet molecularly characterized, isolate collected in Piracicaba, SP, Brazil), CiLV$\mathrm{C}$ clade CRD (isolate collected in Cordeirópolis, SP, Brazil), and CiLV-C2 (kindly provided by Dr. Walther Turizo-Álvarez, Universidad Nacional de Colombia, Bogotá, Colombia).

Viral genome discovery and sequence analysis. Approximately $500 \mathrm{mg}$ of symptomatic tissues from citrus sample 1 were processed as described above. Preparation of both the RNA extract and the next-generation sequencing (NGS) library were carried out as previously defined (Ramos-González et al. 2017). Reads were assembled de novo using both SPAdes, version 3.10.1 (Bankevich et al. 2012), available in Geneious software package version 10.2.2 (Kearse et al. 2012), and Trinity (Haas et al. 2013), implemented on the Galaxy platform (https://usegalaxy.org) (Afgan et al. 2016). Recovered contigs were compared with viral genome sequences at the National Center for Biotechnology Information database (https://www.ncbi.nlm.nih. gov/genome/viruses/) using BLASTX, and those corresponding to putative viral sequences were selected (NCBI Resource Coordinators 2016; States and Gish 1994). Based on these sequences, a set of primers (Supplementary Table S2) spanning all of the contigs were designed using Primer3 software (Untergasser et al. 2012). Fragments ensued from the amplification of the cDNA ends (SMARTer RACE 5'/3' Kit; Clontech Laboratories, Mountain View, CA) were cloned and both recombinant plasmids comprising the rapid amplification of cDNA ends (RACE) products (five independent clones per end) and each of the fragments covering the viral genome resulting from the overlapping reamplification by RT-PCR were sequenced by the Sanger method. After assembly, the virus recovered from the citrus tree 1 was named citrus chlorotic spot virus Trs1 isolate (CiCSV_Trs1). The genomic sequence of the CiCSV_Trs2 isolate (from citrus tree 2) and that of the CiCSV_Trs3 isolate (found in the beach hibiscus) were obtained via Sanger-based sequencing. Amplicons from Trs 2 and Trs 3 isolates were obtained by RT-PCR using the specific primers for the CiCSV_Trs1 isolate. Virus and isolate names were adopted considering the first identified host (citrus), characteristic symptom (chlorotic spot), city's name of the finding (Teresina $=$ Trs), and order of collection (1 to 3).

Viral sequences were analyzed in silico for the identification of ORF, phylogenetic relationships, and presence of putative functional motives and domains such as signal peptide, nuclear localization signals (NLS), nuclear export signals (NES), glycosylation sites, and transmembrane helices using SignalP 4.1 (Petersen et al. 2011), cNLS Mapper (http://nls-mapper.iab.keio.ac.jp) (Kosugi et al. 2009), NetNES 1.1 Server (http://www.cbs.dtu.dk/services/NetNES/) (la Cour et al. 2004), and TMHMM Server v.2.0 (http://www.cbs.dtu. $\mathrm{dk} /$ services/TMHMM/). Viral nucleotide and deduced amino acid sequences were aligned using CLUSTAL algorithms (Chenna et al. 
2003) implemented in Geneious, version 10.2.2. Maximum clade credibility trees were inferred using a Markov Chain Monte Carlo (MCMC) Bayesian approach implemented on Mr. Bayes plugin at Geneious package under GTR $+\Gamma+$ I substitution model. MCMC convergence was obtained for four independent runs with 10 million generations, which were sufficient to obtain a proper sample for the posterior at MCMC stationarity, assessed by effective sample sizes above 200 .

Detection of CiCSV by RT-PCR. CiCSV was detected using a primer pair specific for the $G$ gene (G_CiCSV-F: 5'-CCTCCTCTT CTAGCGTCAT-3' and G_CiCSV-R: 5'-CTGTTTTGCCCATGCT AC-3'). PCR amplification was carried out using GoTaq reaction

A

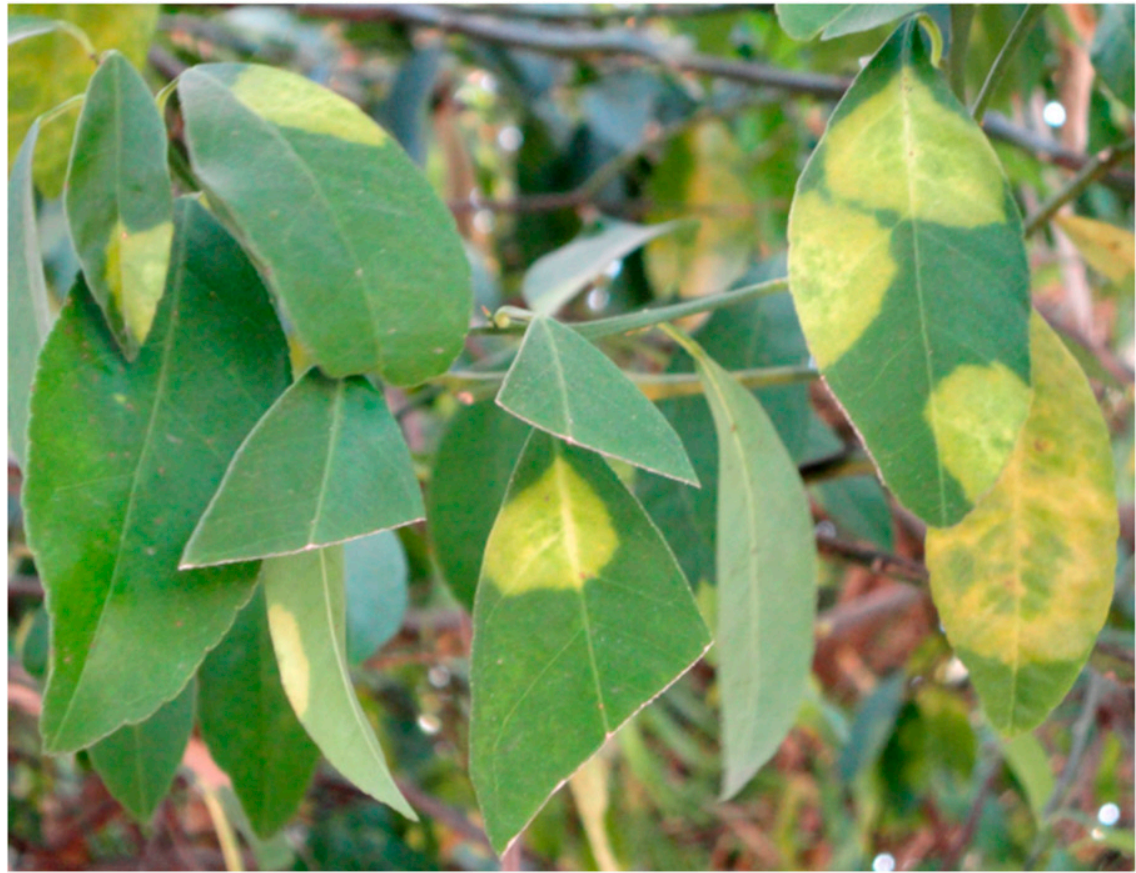

B

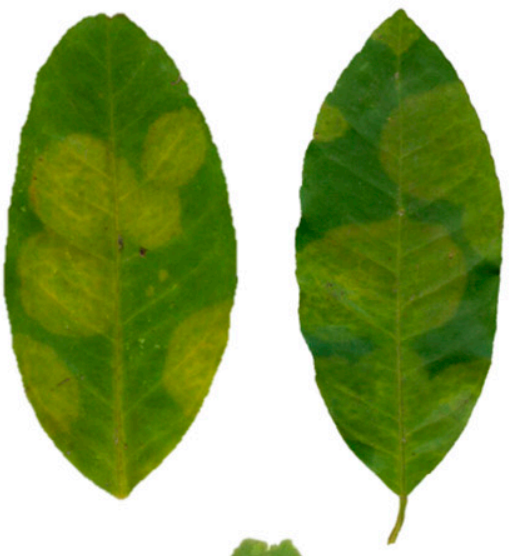

C

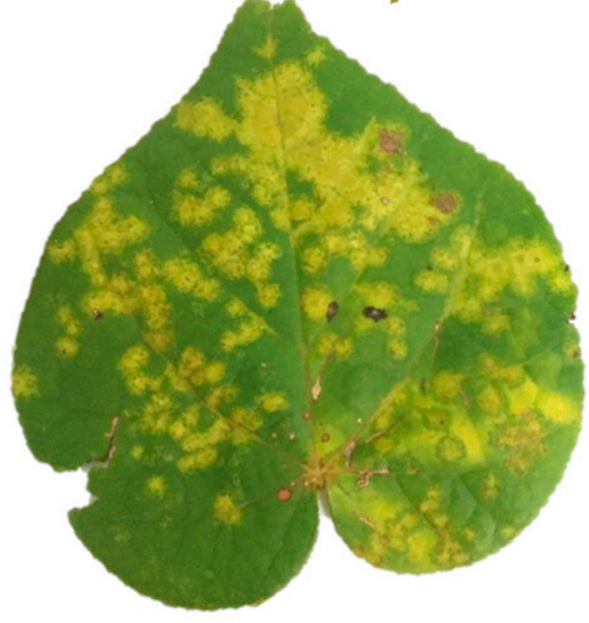

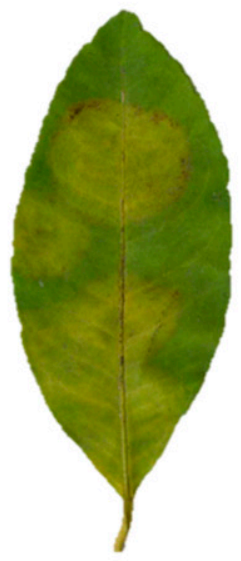
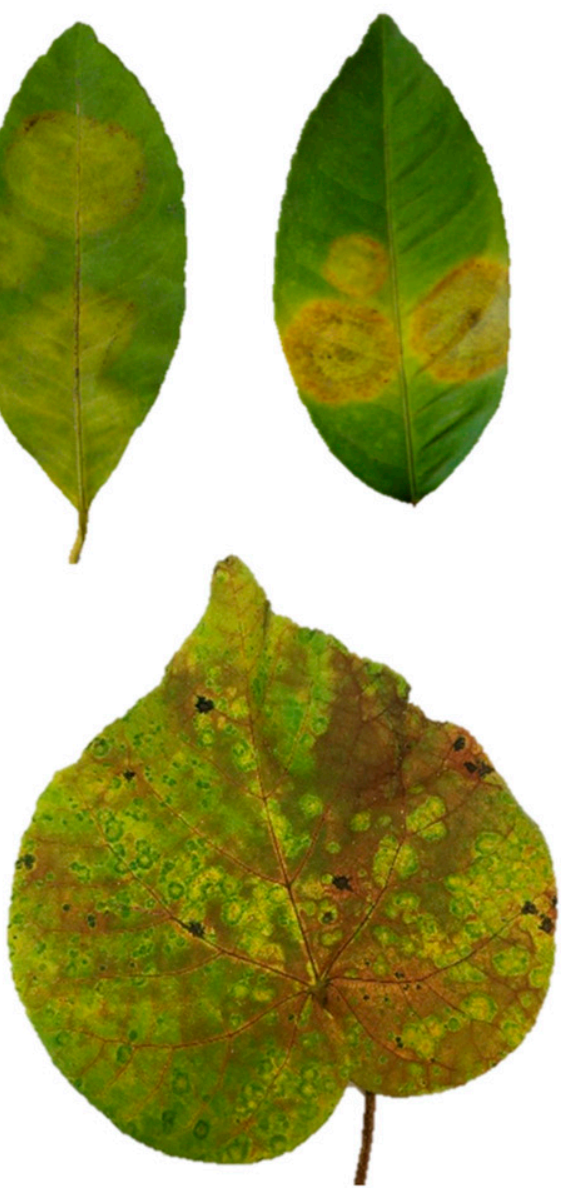

Fig. 1. A, Localized chlorotic symptoms in sweet orange (Citrus sinensis L.) leaves infected with citrus chlorotic spot virus (CiCSV). B, Mature spots or older lesions may have necrotic areas (two leaves at the right). C, Localized chlorotic symptoms in beach hibiscus (Hibiscus tiliaceus L. syn. Talipariti tiliaceum (L.) Fryxell) leaves infected with CiCSV. 
Mix (Promega Corp.), in which $3 \mu$ l of cDNA was used as a template for a $25-\mu 1$ reaction. The thermal cycling was as follows: an initial denaturation step at $95^{\circ} \mathrm{C}$ for $5 \mathrm{~min}$, followed by 35 cycles of $95^{\circ} \mathrm{C}$ for $30 \mathrm{~s}, 58^{\circ} \mathrm{C}$ for $30 \mathrm{~s}$, and $72^{\circ} \mathrm{C}$ for $40 \mathrm{~s}$. An additional final extension for $5 \mathrm{~min}$ at $72^{\circ} \mathrm{C}$ was performed. Moreover, RNA extracts from CiCSV-infected plants were tested using a pair of primers previously described for the detection of CoRSV (CoRSV_F: 5'-GGACCATG AGACAGGAGGTG-3' and CoRSV_R: 5'-CTCTGCCAGTCCTC AATGTG-3') (Kitajima et al. 2011). All amplicons were electrophoretically separated on a $1 \%$ agarose gel. To confirm the identity of the generated fragments, they were purified using Wizard SV Gel and PCR Clean-Up System (Promega Corp.) and further sequenced by the Sanger method.

Mite-mediated virus transmission. In total, 20 mites collected from the beach hibiscus plant were transferred to three healthy Arabidopsis thaliana plants (8, 6, and 6 mites in each plant). Arabidopsis growth conditions and general guidelines for this experiment were as previously described (Ramos-González et al. 2017). After infestation, the arabidopsis growth chamber temperature was kept at $25^{\circ} \mathrm{C}$. Arabidopsis leaves were collected 8 days after the infestation and the surviving mites were recovered and conserved in $90 \%$ ethanol for anatomical identification study. Leaves were carefully rinsed with distilled water to remove remaining mites, eggs, and any other contaminants, and processed for RNA purification. Viral presence in the leaves was detected by RT-PCR using a primer pair specific for the CiCSV $G$ gene and CoRSV $L$ gene (Kitajima et al. 2011). Amplicons were sequenced to confirm their identity.

Mite identification. Mites collected from the symptomatic leaves of citrus and beach hibiscus plants were examined by scanning electron microscopy or mounted for light microscopy. A number of specimens were preserved for further molecular analyses. Mites in different developmental stages, including larva, protonymph, deutonymph, and adults, previously fixed in $90 \%$ ethanol, were mounted on glass slides using Hoyer's medium and examined by differential interference contrast in a Zeiss Axioimager microscope (Carl Zeiss AG, Jena, Germany). The images were digitally registered and the measurements were obtained by means of the microscope software. Moreover, palp setae, microplates, and other morphological details were observed under a JEM IT 300 scanning electron microscope (JEOL, Akishima, Japan). For this, mites were dehydrated in ethanol series, critical point dried using a Leica Critical Point Dryer 300 (Wechsler, Germany), mounted in double-coated carbon tape on stubs, and sputter coated (Baltec SPD 050; Balzers, Liechtenstein) with gold. The specimens were not tightly secured to the carbon tape; thus, it was possible to turn them over to their ventral position for additional imaging. Mite identification was carried out following morphological criteria established for the B. phoenicis sensu lato group (Beard et al. 2015). The holotype of the probably new specimen identified in Teresina, PI, Brazil, collected in sweet orange in February 2017 was deposited (MZLQ3449) at the reference collection of the Zoology Museum in Escola Superior de Agricultura "Luiz de Queiroz”, Universidade de São Paulo, Piracicaba, SP, Brazil.

\section{Results}

Chlorotic spot symptoms in affected sweet orange and beach hibiscus plants in northeastern Brazil are not associated with known cilevirus or dichorhavirus infections. Local chlorotic lesions resembling CL symptoms were detected in leaves of two sweet orange trees located in Teresina, PI, Brazil (Fig. 1A). These spots were generally larger and less bright than those commonly observed in leaves of citrus plants affected by CL (Bastianel et al. 2010; CruzJaramillo et al. 2014; Ramos-González et al. 2017; Roy et al. 2015a). Moreover, necrotic tissues that regularly accompany the CL lesions were seldom seen and, when detected, they were more evident at the boundaries of the lesions (Fig. 1B). Regardless of the differences with the classical CL, total RNA extracts from the lesions were tested by RT-PCR using a set of primers for specific or generic detection of all known cileviruses and dichorhaviruses causing CL (e.g., CiLV-C, CiLV-C2, OFV-citrus, and CiLV-N) (Supplementary Fig. S1). All results were negative, suggesting a different etiological agent associated with CL-like symptoms. Similarly, the putative agent causing the chlorotic spots in beach hibiscus plants (Fig. 1C) was undetectable using the same array of primers.

Morphology of viral particles and cytopathic effects suggest an infection by a dichorha-like virus in sweet orange and beach hibiscus plants. Examination of tissues from the lesions in citrus plants by TEM revealed the presence of large electron-lucent inclusions, referred to as viroplasm, in the nuclei of the infected palisade
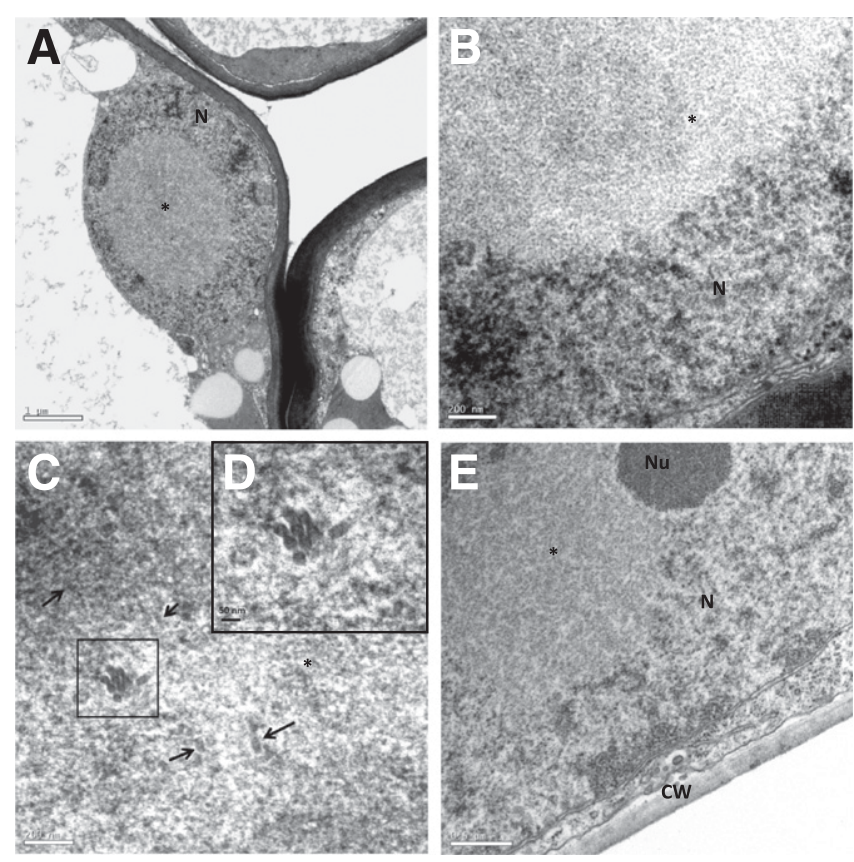

Fig. 2. Transmission electron micrographs of thin sections of chlorotic lesions on citrus chlorotic spot virus-infected beach hibiscus leaves collected in Teresina, State of Piauí, Brazil. A, Nucleus exhibiting electron-lucent viroplasm (*) in spongy parenchyma cells of the infected sweet orange plant. B, Details of the nuclear viroplasm shown in A. C, Rod-like particles approximately $40 \mathrm{~nm}$ wide and up to $100 \mathrm{~nm}$ long appear single (arrows) or grouped (boxed area) interspersed with the electron-lucent viroplasm detected in sweet orange. D, Longitudinal and cross-section details of the rod-like particles highlighted in C. E, Electron-lucent viroplasm in infected cells of beach hibiscus plant. Nucleoplasm area $(\mathrm{N})$, nucleolus $(\mathrm{Nu})$, and cell wall $(\mathrm{CW})$.

\section{RNA1 (6,518 nts)}

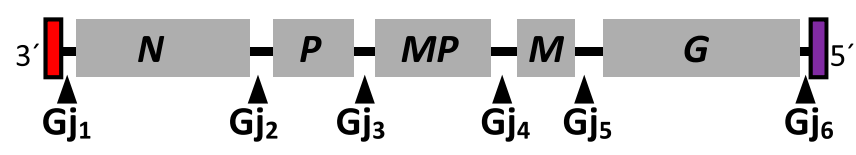

RNA2 (5,987 nts)
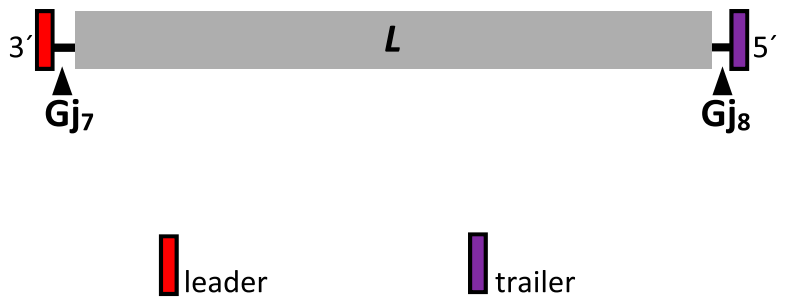

Fig. 3. Genomic organization of citrus chlorotic spot virus. Gray solid boxes indicate viral open reading frame (ORF). Those in the RNA1 are designated as $N=$ nucleocapsid, $P=$ phosphoprotein, $M P=$ movement protein, $M=$ matrix protein, and $G=$ glycoprotein. ORF in the RNA2 encodes the $L$ (RNA-dependent RNA polymerase, $\mathrm{RdRP}$ ) gene. Small boxes designate the leader and trailer sequences on the $3^{\prime}$ and $5^{\prime}$ ends, respectively, of each RNA molecule. Arrowheads show gene junction $(\mathrm{Gj})$ distribution in the genome. 
and spongy parenchyma cells (Fig. 2A and B). Rod-like particles were found in the nucleus, though in a relatively scarce number across the screening of dozens of ultrathin sections (Fig. 2C and D). According to the measurement of at least 20 of them, the rod-shaped particles were approximately $40 \mathrm{~nm}$ wide in cross sections and $100 \mathrm{~nm}$ long in longitudinal sections, suggesting the presence of a typical dichorhavirus (Dietzgen et al. 2014). Neither viroplasm nor rod-like particles were observed in asymptomatic tissues. TEM of thin sections of chlorotic spots on leaves of beach hibiscus also revealed many nuclei containing electron-lucent inclusions (Fig. 2E), similar to the viroplasm found in the infected citrus cells. Spoke-wheel structures, which are frequently observed in dichorhavirus-infected cells (Kitajima et al. 1972, 2003), could not be detected in any of the analyzed samples from the two plant species.

Citrus chlorotic spot virus is a new dichorhavirus and most closely related to CoRSV. NGS and bioinformatic analysis of the RNA library from citrus tree 1 indicated the presence of an unknown virus. Further validation of the assembled sequence by the secondary sequencing of amplicons generated by RT-PCR and RACE definitively revealed the complete genome of a new virus related to known dichorhavirids. No citrus viroid and known-virus contigs were identified in the sequenced sample.

A negative-sense genome of CiCSV_Trs1 isolate was found to be 12,505 nucleotides (nt) in length, subdivided into two strands whose nucleotide sequences were deposited in the GenBank (GB) (RNA1: 6,518 nt, accession number KY700685 and RNA2: 5,987 nt, KY700686). The CiCSV genome has all of the unique features of the bipartite genome of the dichorhaviruses (Fig. 3). Following the convention for this genus, the five ORF detected in the orientation $3^{\prime}$ to $5^{\prime}$ of the RNA1 molecule were consecutively named as genes $N$, $P, M P, M$, and $G$, whereas a sixth ORF, the only one detected in the RNA2 over the entire genome, was identified as the putative $R d R P$ ( $L$ gene). The CiCSV leader and trailer (the stretches of sequences at the two ends of both RNA1 and RNA2) span approximately $200 \mathrm{nt}$.

The complete genome of isolate CiCSV_Trs1 shares best identity values with the genome of CoRSV (GB accession numbers KF812525 and KF812526; RNA1: $70.5 \%$ and RNA2: $76.7 \%$ ) and lower and approximately similar scores with OFV (AB244417 and AB244418) and CiLV-N (KX982176 and KX982179) (RNA1 approximately $55.0 \%$ and RNA2 approximately $62.0 \%$ ) (Table 1 ). Consistently, gene-by-gene analyses revealed the highest values of nucleotide and amino acid identities with CoRSV (Table 1). Deduced sequences of the putative MP $(91.8 \%)$ and $\mathrm{N}(89.5 \%)$ show the best identity values, followed by RdRP $(87.2 \%)$. Analyses using the amino acid sequences of the $\mathrm{P}(81.2 \%), \mathrm{M}(81.0 \%)$, and $\mathrm{G}$ $(69.4 \%)$ unveiled lower levels of identity with their equivalents in the CoRSV genome. Identity values between proteins from CiCSV and their cognates in OFV and CiLV-N were always below $65 \%$.

RNA1 and RNA2 sequences derived from the Trs 2 isolate comprise 6,082 and 5,676 nt (GB accession numbers MG717931 and MG717932), respectively. The 3' and 5' ends of each RNA molecule were not revealed because RACE analysis of this sample was not carried out. Regardless, these segments-RNA1 and RNA2 of Trs 1 and Trs 2 isolates-shared 96.6 and $98.5 \%$ nucleotide identity, respectively (Table 1 ). The deduced amino acid sequences derived from all Trs 2 ORF showed more than $97 \%$ amino acid identity with the cognates in isolate CiCSV_Trs1, that we consider the CiCSV type. The genome sequence of the Trs 3 isolate collected in the beach hibiscus plant was recovered by RT-PCR. RNA1 $(6,078 \mathrm{nt}$, MG970598) and RNA2 (5,632 nt, MG970599) segments from this isolate displayed 95.6 and $98.6 \%$ nucleotide sequence identities, respectively, with their analogous from CiCSV_Trs1 (Table 1).

Deduced proteins from CiCSV_Trs1 display relevant structural and functional motifs. P contains two NLS located in its C-terminal half (amino acid stretches 127 to 136 [peptide PPMKRKVPIQ] and 228 to 238 [peptide RMNRKKKRCLD]). RdRP harbors the motifs Mononeg_RNA_pol (pfam00946), Mononeg_mRNAcap (pfam14318), and paramyx_RNAcap (TIGR04198) present in a large number of $\mathrm{RdRP}$ of mononegavirales, whereas the $\mathrm{N}$ terminus of the $\mathrm{G}$ contains a signal peptide whose cleavage site is located between the residues Ser27 and Gly28 (SignalP D score $=0.761$ ). As observed in the G from other dichorhaviruses (Ramos-González et al. 2017; Roy et al. 2015b), the G of CiCSV shows a transmembrane helix domain placed between the residues 458 and 480 of the putative mature protein (i.e., after the signal peptide removal). This membrane-spanning segment splits the protein into two subdomains: the largest and probably exposed on the virion surface harbors the $\mathrm{N}$ terminus and the smallest domain harbors the $\mathrm{C}$ terminus of the protein. The exposed domain contains two residues of Asn (positions 333 and 369 in the putative mature protein) predicted to be N-glycosylated. N, P, MP, and RdRP encoded by CiCSV also show one or more leucine-rich NES motifs like other dichorhaviruses (e.g., CiLV-N, OFV, and CoRSV) (Kondo et al. 2013; Ramalho et al. 2014; Ramos-González et al. 2017).

Phylogenetic analysis using the sequences of the N, G, and RdRP (L) proteins of a large number of plant-infecting rhabdoviruses supports the assignment of CiCSV to the genus Dichorhavirus (Fig. 4). In the three trees, the sequences of CiCSV grouped together with its cognates from CoRSV, defining a topology in which definitive and putative members of this genus are redistributed in three lineages that we suggest calling subgroups OFV, CoRSV, and CiLV-N. In trees using $\mathrm{N}$ and $\mathrm{G}$ proteins, the dichorhavirus's branches were clearly separated from those containing other plant-infecting rhabdoviruses. This difference was less pronounced in the tree constructed based on $\mathrm{L}$ proteins. On the three generated trees, clade credibility values reached high posterior probabilities $(>0.95)$.

CiCSV can be specifically identified by using primers based on its $G$ gene and detected by primers designed for the detection of $L$ gene from CoRSV. A pair of primers targeting $500 \mathrm{bp}$ of the $G$ gene was selected to establish a specific detection test for CiCSV and to guide further epidemiologic studies. Samples from six different leaves detached from the two naturally infected citrus trees (samples 1 and 2) yielded positive in the RT-PCR tests, whereas no results were obtained using samples from other plants infected with CiLV-C, CiLV-C2, CiLV-N, OFV-citrus, OFV-orchid, CoRSV, or

Table 1. Nucleotide and deduced amino acid identities between citrus chlorotic spot virus Trs1 isolate (CiCSV_Trs1) and the isolates Trs2 and Trs3 and known dichorhaviruses

\begin{tabular}{|c|c|c|c|c|c|}
\hline \multirow[b]{2}{*}{ CiCSV_Trs $1^{b}$} & \multicolumn{5}{|c|}{ Nucleotide/amino acid $^{\mathbf{a}}$} \\
\hline & CiCSV_Trs2 & CiCSV_Trs3 & CiLV-N & OFV & CoRSV \\
\hline RNA1 & 96.6/- & 95.6/- & $55.2 /-$ & $53.0 /-$ & $70.5 /-$ \\
\hline$N$ & $97.5 / 99.6$ & $95.0 / 99.6$ & $61.0 / 58.3$ & $57.1 / 50.4$ & $78.6 / 89.5$ \\
\hline$P$ & $98.3 / 100$ & $96.5 / 100$ & $54.3 / 44.5$ & $51.0 / 33.6$ & $77.3 / 81.2$ \\
\hline$M P$ & $97.4 / 98.8$ & $97.7 / 99.4$ & $62.1 / 58.5$ & $60.0 / 54.2$ & $81.2 / 91.8$ \\
\hline$M$ & $97.1 / 99.5$ & $96.7 / 98.9$ & $58.3 / 47.8$ & $51.5 / 39.7$ & $75.9 / 81.0$ \\
\hline$G$ & $95.2 / 97.2$ & $95.4 / 97.0$ & $51.8 / 37.8$ & $47.7 / 29.8$ & $67.6 / 69.4$ \\
\hline RNA2 & 98.5/- & 98.6/- & $62.1 /-$ & $60.8 /-$ & 76.7/- \\
\hline$L$ & $98.5 / 99.2$ & $98.6 / 98.9$ & $63.4 / 64.1$ & $61.8 / 58.4$ & $77.1 / 87.2$ \\
\hline
\end{tabular}

${ }^{\mathrm{a}}$ CiLV-N = Citrus leprosis virus N (GenBank accession numbers KX982176 and KX982179), OFV = orchid fleck virus (AB244417 and 244418), and CoRSV = coffee ringspot virus (KF812525 and KF812526).

${ }^{\mathrm{b}} N, P, M P, M, G$, and $L=$ nucleocapsid, phosphoprotein, putative movement protein, matrix protein, glycoprotein, and RNA-dependent RNA polymerase genes, respectively. 
ClCSV (Fig. 5A). Two of six amplicons, one corresponding to each tree, were sequenced (GB accession numbers MG717933 and MG717934). They showed $>98 \%$ nucleotide sequence identity with the cognate stretches in the RNA1 from CiCSV_Trs1 (KY700685) and CiCSV_Trs2 (MG717931) isolates, respectively. On the other hand, amplicons of 394 bp corresponding to CiCSV RNA2 were successfully amplified by primers designed for the detection of the $L$ gene from CoRSV (Kitajima et al. 2011). These amplicons showed electrophoretic mobility similar to that from CoRSV-infected plants in $1 \%$ agarose gel (Fig. 5B). Sequences of the generated amplicons (one from each citrus plant, GB accession numbers MG727716 and
MG727717) showed $>98.5 \%$ nucleotide sequence identity with the cognate sequences in the RNA2 of CiCSV_Trs1 (KY700686) and CiCSV_Trs2 (MG717932) isolates, respectively, but 77.0 to $78.0 \%$ nucleotide sequence identity with the equivalent genome region in the CoRSV genome.

CiCSV $G$ gene-specific and CoRSV $L$ gene primers were also used to analyze the chlorotic spot tissues in beach hibiscus (Fig. 6, lanes 9 and 10). Amplicons of 500 and $394 \mathrm{bp}$ were obtained with the primers corresponding to $G$ and $L$ genes, respectively, suggesting the presence of a CiCSV-like virus in this host. Recovered fragments showed $>98 \%$ nucleotide sequence identity with sequences of the Trs1 isolate.
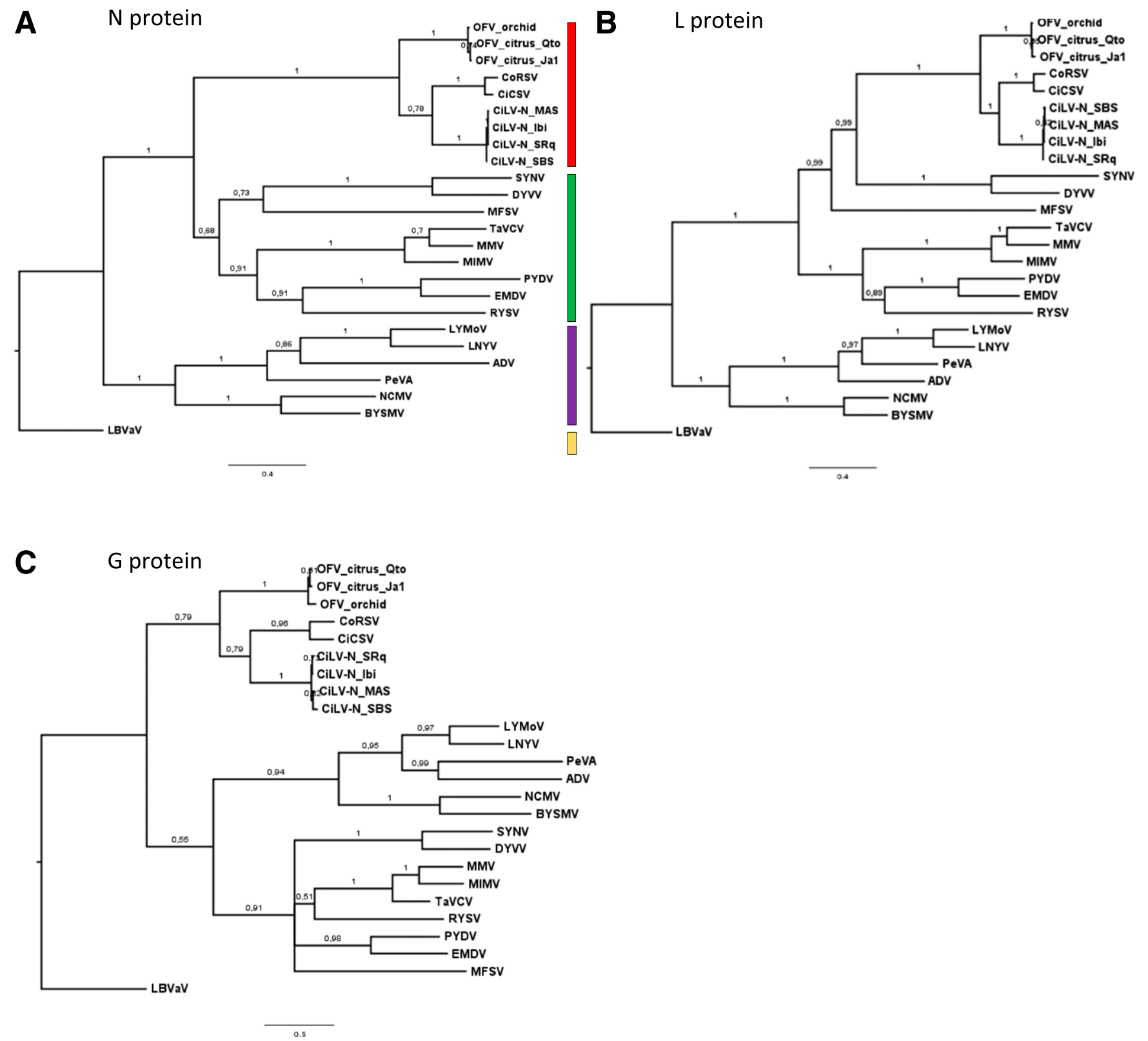

\section{Dichorhavirus \\ Nucleorhabdovirus \\ Cytorhabdovirus}

Varicosavirus

Fig. 4. Phylogenetic reconstruction for plant-infecting viruses of the family Rhabdoviridae. Bayesian maximum clade credibility trees were inferred using the amino acid sequences of A, nucleocapsid protein (N); B, RNA-dependent RNA polymerase (L); and C, glycoprotein (G) of members of the genera Dichorhavirus, Cytorhabdovirus, Nucleorhabdovirus, and Varicosavirus. Trees were inferred using a Markov Chain Monte Carlo (MCMC) of 10 million generations. Lettuce big-vein associated virus (LBVaV)-derived sequences were used as outgroup. CiLV-N = Citrus leprosis virus N, CoRSV = coffee ringspot virus, CiCSV = citrus chlorotic spot virus, OFV = orchid fleck virus, DYVV = datura yellow vein virus, SYNV = sonchus yellow net virus, MFSV = maize fine streak virus, PYDV = potato yellow dwarf virus, EMDV = eggplant mottled dwarf virus, RYSV = rice yellow stunt virus, MIMV = maize Iranian mosaic virus, $\mathrm{MMV}=$ maize mosaic virus, TaVCV = taro vein chlorosis virus, $\mathrm{BYSMV}=$ barley yellow striate mosaic virus, $\mathrm{NCMV}=$ northern cereal mosaic virus, $\mathrm{ADV}=$ alfalfa dwarf virus, PeVA = persimmon virus A, LNYV = lettuce necrotic yellows virus, and LYMoV = lettuce yellow mottle virus. Bar size below each tree indicates the average number of amino acid substitutions per site. 
Arabidopsis plant is an experimental host of CiCSV. Eight days after infestation with a mix of Brevipalpus mites recovered from the beach hibiscus plant, mild yellowish lesions were observed in some leaves of the three inoculated arabidopsis plants. Viral presence was detected in two leaves per each plant by using both CiCSV $G$ genespecific and CoRSV $L$ primers in the RT-PCR tests (Fig. 6, lanes 5 to 8). Some amplicons were purified and their sequences (GB accession numbers MG970600 and MG970601) compared with the CiCSV_Trs1 and CiCSV_Trs3 genomes (KY700685, KY700686, MG970598, and MG970599). Both amplicons showed $>93$ and $98.0 \%$ nucleotide sequence identity with the analogous sequences of the Trs1 and Trs3 isolates, respectively.

At least two types of Brevipalpus mites are found in association with CiCSV symptoms. The number of Brevipalpus mites found infesting beach hibiscus was more than twice as many as that found in the infected citrus plants. Morphoanatomical examination of the adult mites collected from beach hibiscus trees allowed us to identify the presence of $B$. yothersi and another group of Brevipalpus mites that, though similar to B. yothersi, showed some morphological differences (Fig. 7). Accordingly, they were temporarily designed as $B$. aff. yothersi regarding their best resemblance to specimens of that species and following the consensus about the use of qualifiers for provisional taxonomic status (aff. = abbreviation of affinis, from the Latin for "has affinity with") (Sigovini et al. 2016). B. aff. yothersi mites were the only type that we could find in citrus plants.

$B$. aff. yothersi (Fig. 7A) as well as B. yothersi (Fig. 7F) mites show the dorsal opisthosomal setae $c 1, c 3, d 1, d 3, e 1, e 3, f 3, h 1$, and $h 2$ but the seta $f 2$ is absent. In $B$. aff. yothersi, the propodosoma shows crateriform pores in their center, forming irregular cells posteriorly and small cells anteriorly, a rostral shield, and a broad flat projection extending over coxae I-II (Fig. 7A and B). The B. yothersi cuticle is smooth in the propodosoma anteriorly and posteriorly, and weakly reticulate (Fig. 7F and G). Dorsal opisthosoma between $c 1-c 1$ and $d 1-d l$ in $B$. aff. yothersi mites form regular cells whereas, in $B$. yothersi, it is weakly reticulate. In both type of specimens, a light V-shaped fold posterior to $e 1-e 1$ and a sublateral cuticle reticulate, with irregular polygons becoming wrinkled on the margins (Fig. 7A, B, F, and G).

Ventral plate cuticles of the $B$. aff. yothersi mites present elongated and transversal bands in the center and small cells in the lateral area; their genital plates have a cuticle with uniform bands (Fig. 7C). In B. yothersi, the cuticle forms small, round cells in the ventral plate and large cells on the genital plate (Fig. $7 \mathrm{H})$. The palp femorogenu exhibits a dorsal seta setiform and is barbed in the two types of individuals, being longer in $B$. aff. yothersi. In both mites, the tarsus II bears two solenidia and the spermatheca shows a long, narrow duct ending in a sclerotized oval vesicle with thick distal stipe. In $B$. yothersi, the lumen of the vesicle is larger (Fig. 7E and J). Dorsal microplates of $B$. aff. yothersi mites are separate, individual, and irregularly shaped, with a series of small soft punctuations forming lines in different directions (Fig. 7D). In B. yothersi, microplates show different ornamentation and are composed of a series of parallel ridges (Fig. 7I). B. aff. yothersi body sizes are as follows: distance between setae $v 2$ and $h 1=203 \mu \mathrm{m}$ (range 198 to $210 \mu \mathrm{m}$ ), $c 3$ to $c 3=$ $138 \mu \mathrm{m}$ (range 130 to $145 \mu \mathrm{m}$ ), and palp femorogenu setae $14 \mu \mathrm{m}$ (range 10 to $16 \mu \mathrm{m}$ ). For $B$. yothersi, the body sizes are as follows: $v 2$ to $h 1=207 \mu \mathrm{m}$ (range 200 to $215 \mu \mathrm{m}$ ), $c 3$ to $c 3=146 \mu \mathrm{m}$ (range 137 to $150 \mu \mathrm{m}$ ), and palp femorogenu setae $=10 \mu \mathrm{m}$ (range 8 to $11 \mu \mathrm{m})$.

Mites from the hibiscus plant that were further used in the CiCSV transmission experiment were anatomically examined. Three of the five adults recovered from the infected arabidopsis plants after the

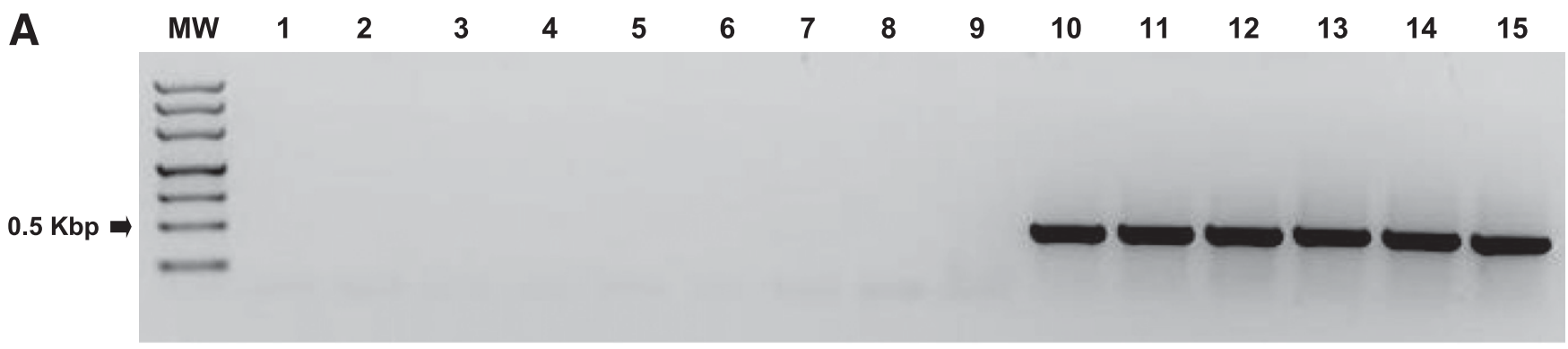

B

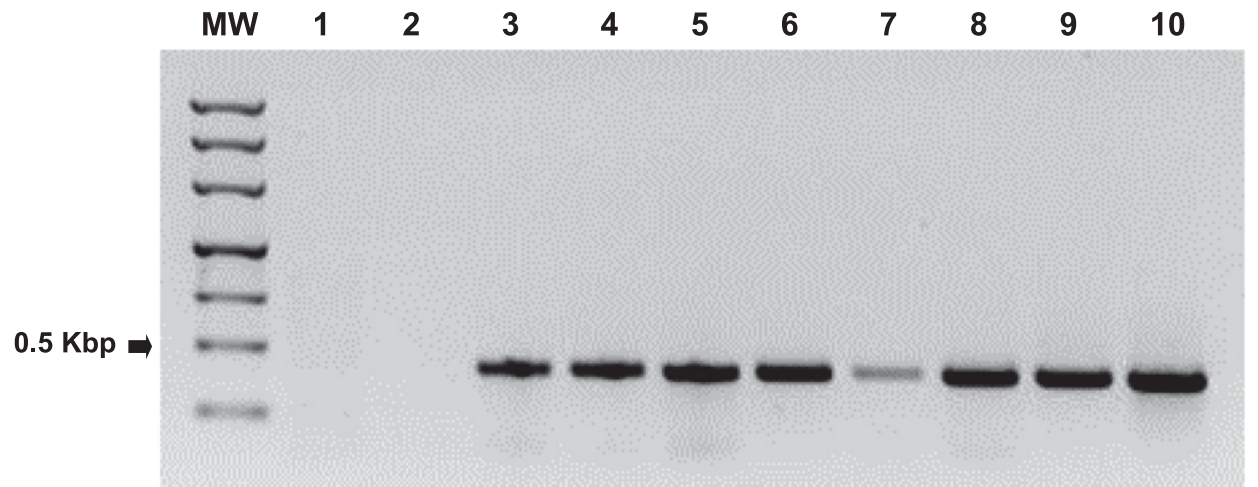

Fig. 5. Analysis of reverse-transcription polymerase chain reaction (RT-PCR) amplicons for detection of citrus chlorotic spot virus (CiCSV) using $1 \%$ agarose gel electrophoresis. A, Primers are specific for the detection of glycoprotein $(G)$ gene from CiCSV. MW = molecular weight marker, M1121 Ladder (Sinapse Biotechnology, Brazil). Lane $1=$ Reversetranscription blank; lane 2 = asymptomatic leaf from CiCSV-infected sweet orange tree (plant 1), Teresina, Pl; lane 3 = CiLV-C-infected citrus tree, Guaimbe, SP; lane $4=$ CiLV-C2infected citrus tree, Colombia; lane $5=$ CiLV-N-infected citrus tree, São Roque, SP; lane $6=$ orchid fleck virus (OFV)-citrus-infected citrus tree, Mexico; lane $7=$ OFV-infected orchid plant, Piracicaba, SP; lane 8 = coffee ringspot virus (CoRSV)-infected coffee plant, Limeira, SP; lane 9 = CICSV-infected Clerodendrum plant, Piracicaba, SP; lanes 10 to 12 = chlorotic lesions from three independent leaves collected in a CiCSV-infected sweet orange tree (plant 1), Teresina, PI; lanes 13 to $15=$ chlorotic lesions from three independent leaves collected in a CiCSV-infected sweet orange tree (plant 2), Teresina, PI. B, RT-PCR products using primers for the detection of the RNA-dependent RNA polymerase $(L)$ gene from CoRSV. MW = molecular weight marker, M1121 ladder. Lane $1=R T$ blank; lane $2=$ PCR blank; lanes 3 to $8=$ chlorotic lesions from two sweet orange trees, Teresina, PI; lanes 9 and $10=$ chlorotic lesions from two CoRSV-infected coffee plants collected in the cities of Piracicaba and Limeira, SP, Brazil, respectively. 
end of the experiment were identified as $B$. yothersi, and the others as $B$. aff. yothersi.

\section{Discussion}

In this work, the complete genome sequence of a new virus associated with CL-like symptoms is identified and characterized. The virus, tentatively called CiCSV, was first discovered infecting two sweet orange trees and subsequently detected in beach hibiscus plants, both occurring in the urban zone of Teresina, State of Piauí, in the northeastern region of Brazil. Viral sequences from three different sources showed more than $95 \%$ of nucleotide sequence identity among them. Both viral genomic structure and phylogenetic analysis indicated a close relationship of CiCSV with CoRSV and other members of the genus Dichorhavirus.

Genus Dichorhavirus was recently approved in the International Committee on Taxonomy of Viruses classification (Afonso et al. 2016) to accommodate bipartite rhabdoviruses transmitted by false spider mites of the genus Brevipalpus (Dietzgen et al. 2014, 2017). Pairwise comparisons of the nucleotide and deduced amino acid sequences from the three known dichorhaviruses reveal a relatively wide gap of genomic sequence identity between them, suggesting a presumed extensive speciation process from a putative common ancestor. Indeed, the identity values from the comparisons involving the pairs OFV and CoRSV, CiLV-N and OFV, and CiLV-N and CoRSV do not exceed 64.0\% (Ramalho et al. 2014; Ramos-González et al. 2017; Roy et al. 2015a). Partially supported by these data, preliminary rules for species demarcation within the genus Dichorhavirus have contemplated a minimum nucleotide sequence divergence of $25 \%$ in the $L$ gene and $10 \%$ in the whole genome (Dietzgen et al. 2014). Different from what it has been seen, CiCSV appears to be less divergent from CoRSV than to other dichorhaviruses, and its genome sequence only partially fulfills the rules for its identification as a putative new species in the genus. Although the comparisons involving the RNA1 (best score $70.5 \%$ with CoRSV) and RNA2 (best score $76.7 \%$ with CoRSV) molecules show values lower than the adopted threshold (90\%), the resulting value from the analysis of the $L$ genes from CiCSV and CoRSV reaches $77.1 \%$ (i.e., slightly over the established cut-off value of $75 \%$ ). The ambiguity ensuing from the analyses of the two criteria does not make obvious an accurate classification of CiCSV. However, although the intraspecific variability of dichorhaviruses has not been extensively studied, the divergence values between known isolates of OFV and CiLV-N are lower than 10 and $8 \%$, respectively (Cruz-Jaramillo et al. 2014; Kondo et al. 2017; Ramos-González et al. 2017; Roy et al. 2013b). Taking into account these data, we chose to propose CiCSV as a new species, because the virus meets one of the criteria for the species demarcation in the genus, the second one is at the borderline, and in summary, the divergence of its nucleotide sequence with that from CoRSV is noticeably higher than the intraspecific diversity observed in other dichorhaviruses. However, we are aware that the addition of novel dichorhavirus sequences and the analysis of the trends of the identity profiles at both the nucleotide and amino acid levels between them will help to better address CiCSV classification.

In addition to the implications for viral classification, fluctuations in the nucleotide sequence identity throughout the CiCSV and CoRSV genomes effectively affect the results of molecular tools addressed to detect them. The pair of primers designed in this work to target the $G$ gene of CiCSV specifically identifies this virus, without amplification from samples containing CoRSV or any other known dichorhavirus, while primers previously available for the detection of RNA2 of CoRSV (Kitajima et al. 2011) also detect CiCSV. This latter result, a consequence of the high conservation ( $\geq 90 \%$ identity) of the target sequences of these primers inside the CiCSV $L$ gene, warns of the possibility of misidentification of these viruses in RT-PCR tests using them. However, from a practical point of view, the appropriate usage of these specific $G$ gene and generic $L$ gene primers might provide a suitable tool supporting epidemiological and phylogeographic studies of dichorhaviruses, particularly CiCSV and CoRSV.

Severity and morphology of distinguishing macroscopic symptoms caused by a viral infection may result from a combination of factors, including viral and host genotypes, abiotic influences, and concomitant infections with viruses and other pathogens (Kwak et al. 2016; Prasch and Sonnewald 2013). CL is classically characterized by the presence of small chlorotic spots in which necrotic areas are regularly observed in leaves, twigs, and fruit. Leaves from the two sweet orange plants infected by CiCSV showed unusually large chlorotic spots. The presence of necrotic tissues was rarely observed. In beach hibiscus, CiCSV infection also resulted in classic chlorotic spots, which become delimited by a green border in the senescent leaves. In broad terms, CiCSV symptoms in leaves from its two known hosts more closely resemble symptoms of CoRSV infection in coffee leaves and berries than classic CL. Perhaps molecular similarities between these two viruses may account for symptom resemblances in their respective hosts. CoRSV infection produces chlorotic irregular spots and ringspots with dark green or brownish borders and, occasionally, with a small central necrotic area (Chagas et al. 2003; Kitajima et al. 2011; Ramalho et al. 2014). Infected immature berries show whitish or yellowish areas that turn into greenish spots in mature fruit (Chagas et al. 2003). Unfortunately, at least for the time being, affected citrus plants did not bear fruit; therefore, symptoms in the putative CiCSV-infected plants, if any, could not be described yet. Regardless, this evidence unveils the existence of a spectrum of symptoms caused by dichorhaviruses and the lack of knowledge about the mechanisms underlying them.

Brevipalpus mites are the only identified vectors for viruses of the genus Cilevirus and Dichorhavirus (Alberti and Kitajima 2014). B. yothersi and B. papayensis mites transmit CiLV-C, whereas

CiCSV $G$ gene detection
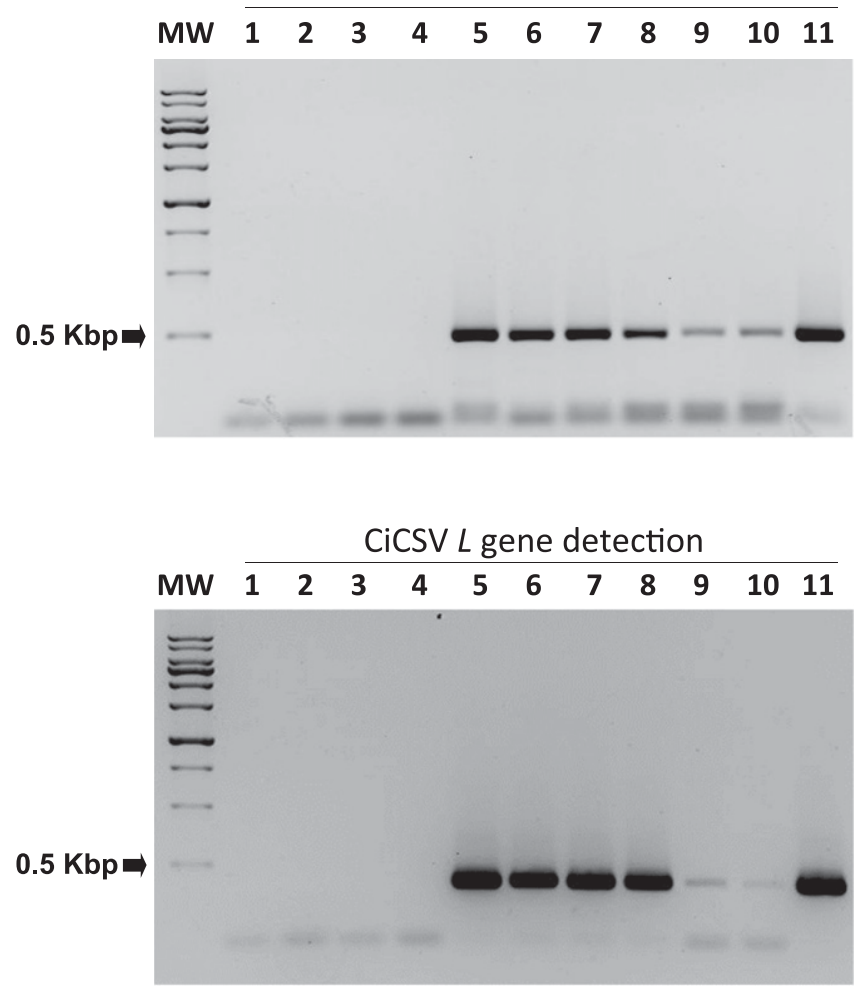

Fig. 6. Analysis of reverse-transcription polymerase chain reaction (RT-PCR) products for detection of citrus chlorotic spot virus (CiCSV)-specific amplicons in naturally infected beach hibiscus and in experimental host arabidopsis using $1 \%$ agarose gel electrophoresis. Results obtained using primers for the detection of glycoprotein $(G)$ and $L$ genes are shown on top and bottom gels, respectively. MW $=$ molecular weight marker, M1181 ladder (Sinapse Biotechnology, SP, Brazil). Lane $1=$ RT blank, lane $2=$ PCR blank, lane $3=$ tissue fragment of the leaf asymptomatic area from CiCSV-infected beach hibiscus, lane $4=$ asymptomatic leaf from arabidopsis plant, lanes 5 and $6=$ symptomatic leaves from CiCSV-infected arabidopsis plant 1, lanes 7 and $8=$ symptomatic leaves from CiCSV-infected arabidopsis plant 2 , lanes 9 and $10=$ chlorotic leaf areas from two independent leaves collected in CiCSV-infected beach hibiscus, lane $11=$ CiCSV-infected sweet orange tree, Teresina, PI. 
B. yothersi mites are the only known vector of CiLV-C2 (León et al. 2017; Nunes et al. 2018; Tassi et al. 2017). B. californicus mites are the vectors of OFV, whereas mites of the species B. phoenicis sensu stricto vector CiLV-N in Brazil (García-Escamilla et al. 2017; Kondo et al. 2003; Ramos-González et al. 2017). Nevertheless, despite the efforts to revisit the B. phoenicis sensu lato group, Brevipalpus spp. have not yet been accurately identified (Beard et al. 2015; Navia et al. 2013) and, thus, the number of mite species actually involved in virus transmission and their role in viral epidemiology are largely unknown.

Based on their morphological characteristics, two different groups of mites were identified in association with CiCSV infection. Most of the collected mites in the beach hibiscus and those recovered from the arabidopsis plants used in the experimental transmission of CiCSV were identified as $B$. aff. yothersi. The description of these mites collected from beach hibiscus and citrus plants best matched with that of the B. yothersi holotype (Beard et al. 2015) but showed several inconsistencies. The main differences were observed in the size or the form of the following structures: microplates, reticulation in the dorsal (propodosoma, the area between $c l-h l$ and lateral areas) and ventral (ventral and genital plates) regions, and palp femorogenu setae. Based on these data, these individuals were tentatively described as $B$. aff. yothersi. Further work will be carried out using genetic markers in order to define whether these mites represent a morphotype of $B$. yothersi or a new species within the genus Brevipalpus. Moreover, because the two types of mites were unintentionally used during the experimental transmission of CiCSV, whether one or both kinds vector CiCSV is a point to be investigated. Recently, molecular characterization of Brevipalpus mites collected in sweet orange orchards in Mexico and Brazil revealed the existence of a greater genetic diversity within Brevipalpus populations than previously described (Sánchez-Velázquez et al. 2015). Similarly, the failed attempt to characterize all of the diversity of CiCSV-associated mite
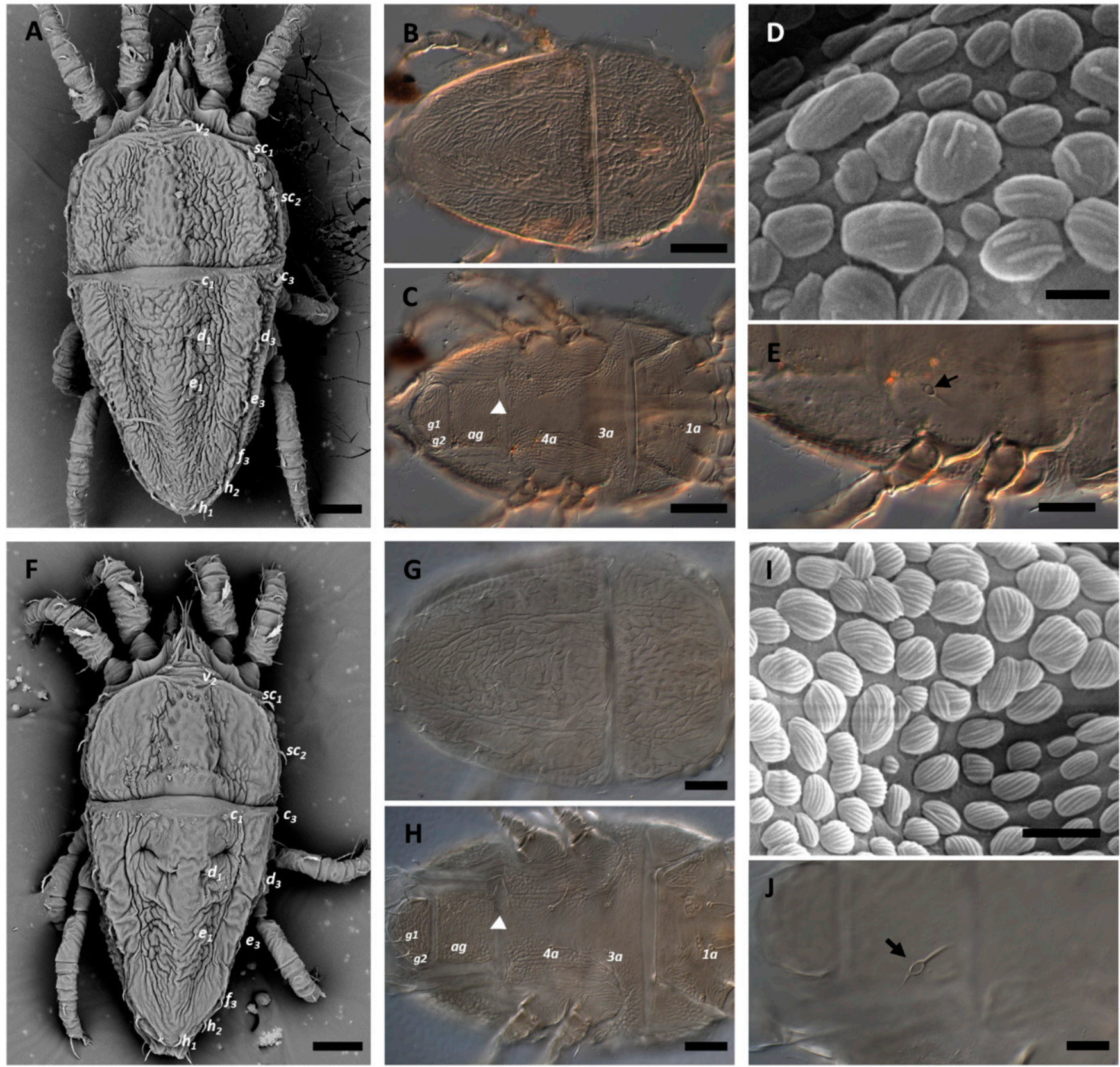

J

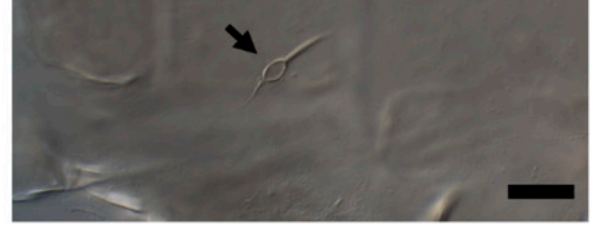

Fig. 7. Microphotographs of $\mathbf{A}$ to $\mathbf{E}$, Brevipalpus aff. yothersi and $\mathbf{F}$ to $\mathrm{J}, B$. yothersi. A and $\mathbf{F}$, Scanning electron microscopy (SEM) micrographs of the cuticle of dorsum showing the propodosoma setae $s c 1, s c 2$, and $v 2$ and the opisthosoma setae $c 1, c 3, d 1, d 3, e 1, e 3, f 3, h 1$, and $h 2$. B and $\mathbf{G}$, Differential interference contrast (DIC) micrographs of dorsal view of the reticulation pattern. $\mathbf{C}$ and $\mathbf{H}, \mathrm{DIC}$ micrographs of the ventral view of the cuticle, genital, and ventral plates with different ornamentations indicated by white arrowheads. Setae 1a, 3a, 4a, ag, g1, g2, ps1, and ps2 are designated. D and I, SEM micrographs of the microplates. E and J, DIC micrographs showing the oval vesicle with a distal stipe of spermatheca (black arrows). Calibration bars: $\mathrm{A}$ and $\mathrm{F}=25 \mu \mathrm{m} ; \mathrm{B}, \mathrm{C}, \mathrm{G}$, and $\mathrm{H}=40 \mu \mathrm{m} ; \mathrm{D}=1 \mu \mathrm{m} ; \mathrm{I}=0.5 \mu \mathrm{m}$; and $\mathrm{E}$ and $\mathrm{J}=20 \mu \mathrm{m}$. 
species launches a novel challenge whose answer will be a further step aimed at the comprehension of the diversity of Brevipalpus mites and their interaction with the transmitted viruses.

Identification and characterization of CiCSV have expanded our knowledge about the novel genus Dichorhavirus and have raised important questions regarding the taxonomy criteria to assign new species to it. Moreover, the existence of Brevipalpus mites whose morphology does not perfectly match with any of the anatomical descriptions from known species of its genus has been revealed. In our opinion, these two subjects and the growing diversity of viral species causing CL-like symptoms as well need to be highlighted and carefully debated in future work based on novel findings. In this sense, our laboratory is currently processing data involving new infections putatively caused by uncharacterized dichorhaviruses and Brevipalpus mites associated with them. Their analyses will shed light concerning this important issue.

\section{Acknowledgments}

We thank P. Faria de Toledo, undergraduate student of Universidade São Camilo, São Paulo, SP, Brazil, for technical assistance; A. Banguela Castillo for bioinformatics support; and G. Otero-Colina (Colegio de Postgraduados, Texcoco, Mexico) and W. Turizo-Alvarez (Universidad Nacional de Colombia, Bogota, Colombia) for kindly providing cDNA controls used in this work.

\section{Literature Cited}

Afgan, E., Baker, D., van den Beek, M., Blankenberg, D., Bouvier, D., Čech, M., Chilton, J., Clements, D., Coraor, N., Eberhard, C., Grüning, B., Guerler, A., Hillman-Jackson, J., Von Kuster, G., Rasche, E., Soranzo, N., Turaga, N., Taylor, J., Nekrutenko, A., and Goecks, J. 2016. The Galaxy platform for accessible, reproducible and collaborative biomedical analyses: 2016 update. Nucleic Acids Res. 44:W3-W10.

Afonso, C. L., Amarasinghe, G. K., Bányai, K., Bào, Y., Basler, C. F., Bavari, S., Bejerman, N., Blasdell, K. R., Briand, F.-X., Briese, T., Bukreyev, A., Calisher, C. H., Chandran, K., Chéng, J., Clawson, A. N., Collins, P. L., Dietzgen, R. G., Dolnik, O., Domier, L. L., Dürrwald, R., Dye, J. M., Easton, A. J., Ebihara, H., Farkas, S. L., Freitas-Astúa, J., Formenty, P., Fouchier, R. A. M., Fù, Y., Ghedin, E., Goodin, M. M., Hewson, R., Horie, M., Hyndman, T. H., Jiāng, D., Kitajima, E. W., Kobinger, G. P., Kondo, H., Kurath, G., Lamb, R. A., Lenardon, S., Leroy, E. M., Li, C.-X., Lin, X.-D., Liú, L., Longdon, B., Marton, S., Maisner, A., Mühlberger, E., Netesov, S. V., Nowotny, N., Patterson, J. L., Payne, S. L., Paweska, J. T., Randall, R. E., Rima, B. K., Rota, P., Rubbenstroth, D., Schwemmle, M., Shi, M., Smither, S. J., Stenglein, M. D., Stone, D. M., Takada, A., Terregino, C., Tesh, R. B., Tian, J.-H., Tomonaga, K., Tordo, N., Towner, J. S., Vasilakis, N., Verbeek, M., Volchkov, V. E., Wahl-Jensen, V., Walsh, J. A., Walker, P. J., Wang, D., Wang, L.-F., Wetzel, T., Whitfield, A. E., Xiè, J. T., Yuen, K.-Y., Zhang, Y.-Z., and Kuhn, J. H. 2016. Taxonomy of the order Mononegavirales: Update 2016. Arch. Virol. 161:2351-2360.

Alberti, G., and Kitajima, E. W. 2014. Anatomy and Fine Structure of Brevipalpus Mites (Tenuipalpidae)-Economically Important Plant-Virus Vectors. G. Alberti and E. W. Kitajima, eds. Zoologica, Vol. 160.

Arena, G. D., Ramos-González, P. L., Nunes, M. A., Alves, M. R., Camargo, L. E. A., Kitajima, E. W., Machado, M. A., and Freitas-Astua, J. 2016. Citrus leprosis virus $C$ infection results in hypersensitive-like response, suppression of the JA/ET plant defense pathway and promotion of the colonization of its mite vector. Front. Plant Sci. 7:1757.

Bankevich, A., Nurk, S., Antipov, D., Gurevich, A. A., Dvorkin, M., Kulikov, A. S., Lesin, V. M., Nikolenko, S. I., Pham, S., Prjibelski, A. D., Pyshkin, A. V., Sirotkin, A. V., Vyahhi, N., Tesler, G., Alekseyev, M. A., and Pevzner, P. A. 2012. SPAdes: A new genome assembly algorithm and its applications to singlecell sequencing. J. Comput. Biol. 19:455-477.

Bastianel, M., Novelli, V. M., Kitajima, E. W., Kubo, K. S., Bassanezi, R. B., Machado, M. A., and Freitas-Astúa, J. 2010. Citrus leprosis: Centennial of an unusual mite-virus pathosystem. Plant Dis. 94:284-292.

Beard, J. J., Ochoa, R., Braswell, W. E., and Bauchan, G. R. 2015. Brevipalpus phoenicis (Geijskes) species complex (Acari: Tenuipalpidae)-a closer look. Zootaxa 3944:1-67.

Chagas, C. M. M., Kitajima, E. W. W., and Rodrigues, J. C. V. C. V. 2003. Coffee ringspot virus vectored by Brevipalpus phoenicis (Acari: Tenuipalpidae) in coffee. Exp. Appl. Acarol. 30:203-213.

Chenna, R., Sugawara, H., Koike, T., Lopez, R., Gibson, T. J., Higgins, D. G., and Thompson, J. D. 2003. Multiple sequence alignment with the Clustal series of programs. Nucleic Acids Res. 31:3497-3500.

Childers, C. C., French, J. V., and Rodrigues, J. C. V. 2003. Brevipalpus californicus, B. obovatus, B. phoenicis, and B. lewisi (Acari: Tenuipalpidae): A review of their biology, feeding injury and economic importance. Exp. Appl. Acarol. 30:5-28.

Cruz-Jaramillo, J. L., Ruiz-Medrano, R., Rojas-Morales, L., López-Buenfil, J. A., Morales-Galván, O., Chavarín-Palacio, C., Ramírez-Pool, J. A., and Xoconostle-
Cázares, B. 2014. Characterization of a proposed dichorhavirus associated with the citrus leprosis disease and analysis of the host response. Viruses 6 : 2602-2622.

Dietzgen, R. G., Kondo, H., Goodin, M. M., Kurath, G., and Vasilakis, N. 2017 The family Rhabdoviridae: Mono- and bipartite negative-sense RNA viruses with diverse genome organization and common evolutionary origins. Virus Res. 227:158-170.

Dietzgen, R. G., Kuhn, J. H., Clawson, A. N., Freitas-Astúa, J., Goodin, M. M. Kitajima, E. W., Kondo, H., Wetzel, T., and Whitfield, A. E. 2014 Dichorhavirus: A proposed new genus for Brevipalpus mite-transmitted, nuclear, bacilliform, bipartite, negative-strand RNA plant viruses. Arch. Virol. 159:607-619.

Frezzi, M. S. 1940. La lepra explosiva del naranjo. Ministerio de la Agricultura dirección de Sanidad Vegetal, Buenos Aires, Argentina. Bol. Frutas Hortalizas. 5:1-16.

García-Escamilla, P., Duran-Trujillo, Y., Otero-Colina, G., Valdovinos-Ponce, G. Santillán-Galicia, M. T., Ortiz-García, C. F., Velázquez-Monreal, J. J., and Sánchez-Soto, S. 2017. Transmission of viruses associated with cytoplasmic and nuclear leprosis symptoms by Brevipalpus yothersi and B. californicus. Trop. Plant Pathol. 43:1-9.

Haas, B. J., Papanicolaou, A., Yassour, M., Grabherr, M., Blood, P. D., Bowden, J., Couger, M. B., Eccles, D., Li, B., Lieber, M., MacManes, M. D., Ott, M., Orvis, J., Pochet, N., Strozzi, F., Weeks, N., Westerman, R., William, T., Dewey, C. N., Henschel, R., LeDuc, R. D., Friedman, N., and Regev, A. 2013. De novo transcript sequence reconstruction from RNA-seq using the Trinity platform for reference generation and analysis. Nat. Protoc. 8: 1494-1512.

Hartung, J. S., Roy, A., Fu, S., Shao, J., Schneider, W. L., and Brlansky, R. H. 2015. History and diversity of citrus leprosis virus recorded in herbarium specimens. Phytopathology 105:1277-1284.

Kearse, M., Moir, R., Wilson, A., Stones-Havas, S., Cheung, M., Sturrock, S., Buxton, S., Cooper, A., Markowitz, S., Duran, C., Thierer, T., Ashton, B., Meintjes, P., and Drummond, A. 2012. Geneious Basic: An integrated and extendable desktop software platform for the organization and analysis of sequence data. Bioinformatics 28:1647-1649.

Kitajima, E. W., and Alberti, G. 2014. Ultrastructural detection of cytoplasmic and nuclear types of Brevipalpus transmitted viruses. Part 7, pages 174-192 in: Anatomy and Fine Structure of Brevipalpus Mites (Tenuipalpidae)Economically Important Plant-Virus Vectors. G. Alberti and E. W. Kitajima, eds. Zoologica, Vol. 160

Kitajima, E. W., Chagas, C. M., Braghini, M. T., Fazuoli, L. C., Locali-Fabris, E. C., and Salaroli, R. B. 2011. Natural infection of several Coffea species and hybrids and Psilanthus ebracteolatus by the coffee ringspot virus (CoRSV). Sci. Agric. 68:503-507.

Kitajima, E. W., Chagas, C. M., and Rodrigues, J. C. V. 2003. Brevipalpustransmitted plant virus and virus-like diseases: Cytopathology and some recent cases. Exp. Appl. Acarol. 30:135-160.

Kitajima, E. W., Müller, G. W., Costa, A. S., and Yuki, W. 1972. Short, rod-like particles associated with Citrus leprosis. Virology 50:254-258.

Kitajima, E. W., and Nome, C. F. 1999. Microscopia electrónica em virologia vegetal. Pages 75-77 in: Métodos para detectar patógenos sistémicos. D. M. Docampo and S. L. Lenardón, eds. Instituto de Fitopatología y Fisiología Vegetal (IFFIVE), INTA-JICA, Córdoba, Argentina.

Knorr, L. C. 1968. Studies on the etiology of leprosis in citrus. Pages 332-341in: Proc. 4th Conf. Int. Organ. Citrus. Virol. University of Florida Press, Gainesville.

Kondo, H., Chiba, S., Andika, I. B., Maruyama, K., Tamada, T., and Suzuki, N. 2013. Orchid fleck virus structural proteins $\mathrm{N}$ and $\mathrm{P}$ form intranuclear viroplasm-like structures in the absence of viral infection. J. Virol. 87: 7423-7434.

Kondo, H., Hirota, K., Maruyama, K., Andika, I. B., and Suzuki, N. 2017. A possible occurrence of genome reassortment among bipartite rhabdoviruses. Virology 508:18-25.

Kondo, H., Maeda, T., and Tamada, T. 2003. Orchid fleck virus: Brevipalpus californicus mite transmission, biological properties and genome structure. Exp. Appl. Acarol. 30:215-223.

Kosugi, S., Hasebe, M., Tomita, M., and Yanagawa, H. 2009. Systematic identification of cell cycle-dependent yeast nucleocytoplasmic shuttling proteins by prediction of composite motifs. Proc. Natl. Acad. Sci. USA 106:10171-10176.

Kubo, K. S., Stuart, R. M., Freitas-Astúa, J., Antonioli-Luizon, R., Locali-Fabris, E. C., and Coletta-Filho, H. D. 2009. Evaluation of the genetic variability of orchid fleck virus by single-strand conformational polymorphism analysis and nucleotide sequencing of a fragment from the nucleocapsid gene. Arch. Virol. 154:1009-1014.

Kwak, H.-R., Lee, Y.-J., Kim, J., Kim, M.-K., Kim, J.-S., Choi, H.-S., and Seo, J.-K. 2016. A determinant of disease symptom severity is located in RNA2 of broad bean wilt virus 2. Virus Res. 211:25-28.

la Cour, T., Kiemer, L., Mølgaard, A., Gupta, R., Skriver, K., and Brunak, S. 2004 Analysis and prediction of leucine-rich nuclear export signals. Protein Eng. Des. Sel. 17:527-536

León, G., Roy, A., Choudhary, N., and Brlansky, R. 2017. Citrus leprosis transmission by Brevipalpus yothersi mites through non citrus hosts. Corpoica Cienc. Tecnol. Agropec. 18:307-319. 
Locali-Fabris, E. C., Freitas-Astúa, J., and Machado, M. A. 2012. Genus Cilevirus. Pages 1139-1142 in: Virus Taxonomy. Classification and Nomenclature of Viruses. Ninth Report of the International Committee on Taxonomy of Viruses. A. M. Q. King, M. J. Adams, E. B. Carstens, and E. J. Lefkowitz, eds. Elsevier/Academic Press, London.

Locali-Fabris, E. C., Freitas-Astúa, J., Souza, A. A., Takita, M. A., Astúa-Monge, G., Antonioli-Luizon, R., Rodrigues, V., Targon, M. L. P. N., and Machado, M. A. 2006. Complete nucleotide sequence, genomic organization and phylogenetic analysis of citrus leprosis virus cytoplasmic type. J. Gen. Virol. 87:2721-2729.

Melzer, M. J., Sether, D. M., Borth, W. B., and Hu, J. S. 2012. Characterization of a virus infecting Citrus volkameriana with citrus leprosis-like symptoms. Phytopathology 102:122-127.

Mesa, N., Ochoa, R., Welbourn, W., and Evans, G. 2009. A catalog of the Tenuipalpidae (Acari) of the World with a key to genera. Zootaxa 2098:1-185.

Navia, D., Mendonça, R. S., Ferragut, F., Miranda, L. C., Trincado, R. C., Michaux, J., and Navajas, M. 2013. Cryptic diversity in Brevipalpus mites (Tenuipalpidae). Zool. Scr. 42:406-426.

NCBI Resource Coordinators. 2016. Database resources of the National Center for Biotechnology Information. Nucleic Acids Res. 44:D7-D19.

Nunes, M. A., de Carvalho Mineiro, J. L., Rogero, L. A., Ferreira, L. M., Tassi, A., Novelli, V. M., Kitajima, E. W., and Freitas-Astúa, J. 2018. First report of Brevipalpus papayensis as vector of Coffee ringspot virus and Citrus leprosis virus $C$. Plant Dis. 102:1046.

Petersen, T. N., Brunak, S., von Heijne, G., and Nielsen, H. 2011. SignalP 4.0: Discriminating signal peptides from transmembrane regions. Nat. Methods 8: 785-786.

Prasch, C. M., and Sonnewald, U. 2013. Simultaneous application of heat, drought, and virus to Arabidopsis plants reveals significant shifts in signaling networks. Plant Physiol. 162:1849-1866.

Ramalho, T. O., Figueira, A. R., Sotero, A. J., Wang, R., Geraldino Duarte, P. S., Farman, M., and Goodin, M. M. 2014. Characterization of Coffee ringspot virus-Lavras: A model for an emerging threat to coffee production and quality. Virology 464-465:385-396.

Ramos-González, P. L., Chabi-Jesus, C., Guerra-Peraza, O., Breton, M. C., Arena, G. D., Nunes, M. A., Kitajima, E. W., Machado, M. A., and Freitas-Astúa, J. 2016a. Phylogenetic and molecular variability studies reveal a new genetic clade of Citrus leprosis virus C. Viruses 8:153.

Ramos-González, P. L., Chabi-Jesus, C., Guerra-Peraza, O., Tassi, A. D., Kitajima, E. W., Harakava, R., Salaroli, R. B., and Freitas-Astúa, J. 2017. Citrus leprosis virus N: A new dichorhavirus causing citrus leprosis disease. Phytopathology 107:963-976.

Ramos-González, P. L., Sarubbi-Orue, H., Gonzales-Segnana, L., Chabi-Jesus, C., Freitas-Astúa, J., and Kitajima, E. W. 2016b. Orchid fleck virus infecting orchids in Paraguay: First report and use of degenerate primers for its detection. J. Phytopathol. 164:342-347.
Rodrigues, J. C. V., Kitajima, E. W., Childers, C. C., and Chagas, C. M. 2003. Citrus leprosis virus vectored by Brevipalpus phoenicis (Acari: Tenuipalpidae) on citrus in Brazil. Exp. Appl. Acarol. 30:161-179.

Roy, A., Choudhary, N., Guillermo, L. M., Shao, J., Govindarajulu, A., Achor, D., Wei, G., Picton, D. D., Levy, L., Nakhla, M. K., Hartung, J. S., and Brlansky, R. H. 2013a. A novel virus of the genus Cilevirus causing symptoms similar to citrus leprosis. Phytopathology 103:488-500.

Roy, A., Hartung, J. S., Schneider, W. L., Shao, J., Leon, M. G., Melzer, M. J., Beard, J. J., Otero-Colina, G., Bauchan, G. R., Ochoa, R., and Brlansky, R. H. 2015a. Role bending: Complex relationships between viruses, hosts, and vectors related to citrus leprosis, an emerging disease. Phytopathology 105:1013-1025.

Roy, A., Leon, M. G., Stone, A. L., Schneider, W. L., Hartung, J., and Brlansky, R. H. 2014. First report of citrus leprosis virus nuclear type in sweet orange in Colombia. Plant Dis. 98:1162.

Roy, A., Stone, A., Otero-Colina, G., Wei, G., Choudhary, N., Achor, D., Shao, J., Levy, L., Nakhla, M. K., Hollingsworth, C. R., Hartung, J. S., Schneider, W. L., and Brlansky, R. H. 2013b. Genome assembly of citrus leprosis virus nuclear type reveals a close association with orchid fleck virus. Genome Announc. 1: e00519-13. http://genomea.asm.org/content/1/4/e00519-13

Roy, A., Stone, A. L., Shao, J., Otero-Colina, G., Wei, G., Choudhary, N., Achor, D., Levy, L., Nakhla, M. K., Hartung, J. S., Schneider, W. L., and Brlansky, R. H. 2015b. Identification and molecular characterization of nuclear Citrus leprosis virus, a member of the proposed Dichorhavirus genus infecting multiple Citrus species in Mexico. Phytopathology 105:564-575.

Sánchez-Velázquez, E. J., Santillán-Galicia, M. T., Novelli, V. M., Nunes, M. A., Mora-Aguilera, G., Valdez-Carrasco, J. M., Otero-Colina, G., and FreitasAstúa, J. 2015. Diversity and genetic variation among Brevipalpus populations from Brazil and Mexico. PLoS One 10:e0133861.

Sigovini, M., Keppel, E., and Tagliapietra, D. 2016. Open nomenclature in the biodiversity era. Methods Ecol. Evol. 7:1217-1225.

States, D. J., and Gish, W. 1994. Combined use of sequence similarity and codon bias for coding region identification. J. Comput. Biol. 1:39-50.

Tassi, A. D., Garita-Salazar, L. C., Amorim, L., Novelli, V. M., Freitas-Astúa, J. Childers, C. C., and Kitajima, E. W. 2017. Virus-vector relationship in the Citrus leprosis pathosystem. Exp. Appl. Acarol. 71:227-241.

Untergasser, A., Cutcutache, I., Koressaar, T., Ye, J., Faircloth, B. C., Remm, M., and Rozen, S. G. 2012. Primer3-new capabilities and interfaces. Nucleic Acids Res. 40:e115.

Vergani, A. R. 1945. Transmisión y naturaleza de la "lepra explosiva" del naranjo. Instituto Sanidad Vegetal, Ministerio de Agricultura de la Nación, Buenos Aires, Argentina.

Walker, P. J., Firth, C., Widen, S. G., Blasdell, K. R., Guzman, H., Wood, T. G., Paradkar, P. N., Holmes, E. C., Tesh, R. B., and Vasilakis, N. 2015. Evolution of genome size and complexity in the Rhabdoviridae. PLOS Pathog. 11: e1004664 